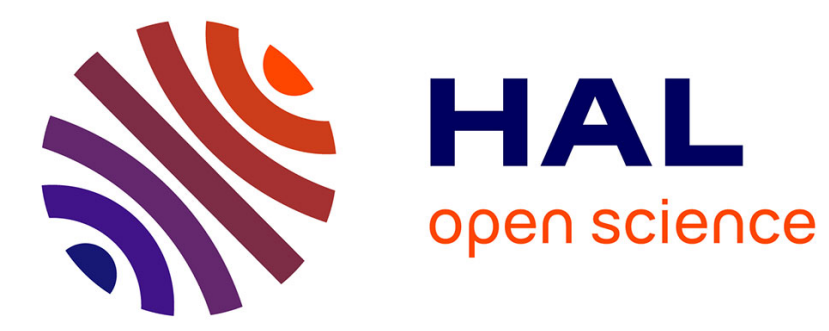

\title{
Exploring the Integration of Maintenance with Production Management in SMEs
}

Marco Macchi, Alessandro Pozzetti, Luca Fumagalli

\section{To cite this version:}

Marco Macchi, Alessandro Pozzetti, Luca Fumagalli. Exploring the Integration of Maintenance with Production Management in SMEs. IFIP International Conference on Advances in Production Management Systems (APMS), Sep 2014, Ajaccio, France. pp.507-514, 10.1007/978-3-662-44739-0_62 . hal-01388585

\section{HAL Id: hal-01388585 \\ https://hal.inria.fr/hal-01388585}

Submitted on 27 Oct 2016

HAL is a multi-disciplinary open access archive for the deposit and dissemination of scientific research documents, whether they are published or not. The documents may come from teaching and research institutions in France or abroad, or from public or private research centers.
L'archive ouverte pluridisciplinaire HAL, est destinée au dépôt et à la diffusion de documents scientifiques de niveau recherche, publiés ou non, émanant des établissements d'enseignement et de recherche français ou étrangers, des laboratoires publics ou privés. 


\title{
Exploring the Integration of Maintenance with Production Management in SMEs
}

\author{
Marco Macchi ${ }^{1}$, Alessandro Pozzetti ${ }^{1}$, Luca Fumagalli ${ }^{1}$ \\ ${ }^{1}$ Department of Management, Economics and Industrial Engineering, Politecnico di Milano, \\ Piazza Leonardo da Vinci 32, 20133 Milano \\ \{marco.macchi, alessandro.pozzetti, luca1.fumagalli\}@polimi.it
}

\begin{abstract}
The paper presents the results of an exploratory research based on 10 SMEs used as case studies with the purpose to observe the state of practices with regard to the integration of maintenance with production management. The research intends to provide an evaluation of the quality of integration by means of a maturity assessment method. The resulting evidences allow an initial concern on strengths and weaknesses of maintenance management and its relationship with production management in SMEs.
\end{abstract}

Keywords: Maintenance management, production management, integration, SME, manufacturing.

\section{Introduction}

The importance of maintenance in manufacturing has been increasing in the recent years [1] considering its effect on the long-term improvement of equipment availability, product quality and production costs [2] and the growing concern that profit and productivity can be improved when maintenance potential is exploited [3]. Nonetheless, maintenance is not yet developed in many industries: according to [4], reporting a survey on 118 companies in Sweden, $55 \%$ from the mechanical industry, relevant weaknesses emerge; we achieved similar evidences in Italy through a survey on 128 manufacturing companies [5]. Nonetheless, it is worth remarking a positive issue with regard to the use of TPM (Total Productive Maintenance), as a good share of companies in the mechanical industry declares TPM as standard practice. Since TPM is an opportunity space for better integration of maintenance with production [6], the aim of this paper is to study the relationship between production and maintenance function within mechanical plants. This is discussed in a wide number of publications; even so, literature is still lacking attention on the integration of maintenance and production within SMEs. Thus the paper aims at providing the results of an exploratory research carried out in 10 SMEs in the wire drawing industry, a sector of the mechanical industry. This industry operates downstream from the steel-making industry and, according to the Comité Européen de la Tréfilerie, in Europe it is composed of nearly 500 active companies, with about 50,000 employees. 
The study starts with the design of the exploratory research (section 2), its implementation is then described (section 3 ) and the results are discussed (section 4) before concluding with limits and next steps for future work (section 5).

\section{Design of the exploratory research}

\subsection{Scope and framework}

Figure 1 summarizes research scope and conceptual framework used to drive the next step of research implementation.

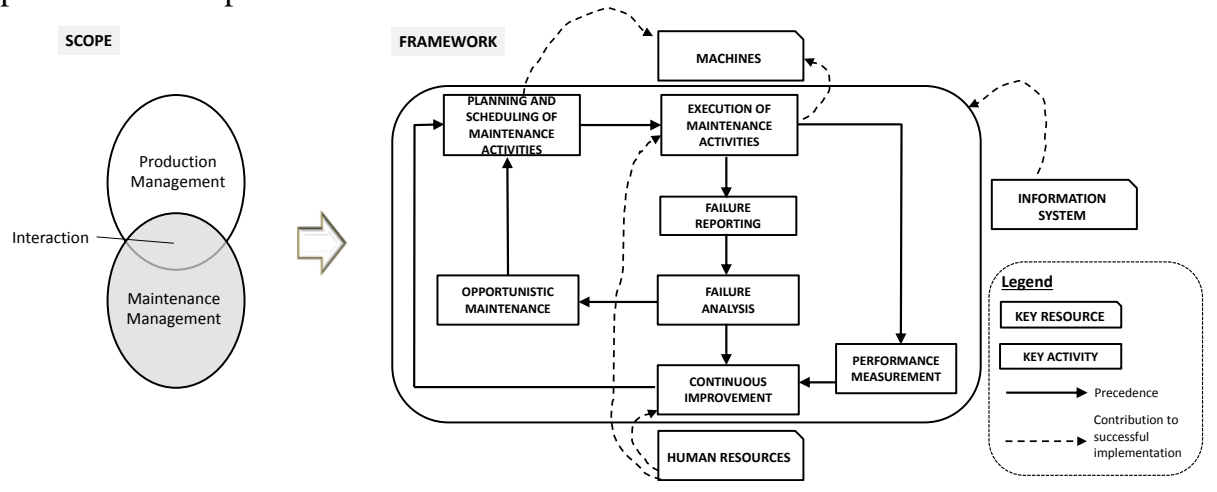

Fig. 1. Reseach scope and conceptual framework

The framework is based on maintenance management with special regard to TPM practices $[6,7]$; further on, due to the scarcity of SMEs-related literature, interviews to 2 SMEs as pilot cases have been carried on, to identify the most important matters perceived in regard to the integration between production and maintenance. As first result of the pilots, the framework includes the information system as key resource to support information and procedures required for the maintenance tasks and the interaction with the production function. Further on, it is worth remarking the logic for continuous improvement as a perceived need in SMEs: in this regard, the machines installed in the company are the entities driving the interaction between production and maintenance function; the human resources are the key resources to contribute to its successful implementation. Other relevant activities were identified in the pilots: i) failure reporting and analysis, enabling the integration by capturing information and knowledge from maintenance and production through simple "tools" (e.g. Ishikawa diagram as suggested by TPM); ii) opportunistic maintenance, whenever the failure creates a repair "opportunity" leading to consider the possibility to anticipate some preventive repairs; iii) maintenance planning and scheduling, that should be driven by the machines' criticality; iii) execution of maintenance activities, requiring training of operators, even production ones for autonomous maintenance; iii) performance measurement, to assess the achievement of production targets through Key Performance Indicators (KPIs). 


\subsection{Target process area}

The conceptual framework was re-organized by defining 6 maintenance process areas as reference model for the implementation step (table 1).

Tab. 1. Process areas and matters of interest for integration within each area

\begin{tabular}{|c|c|}
\hline Process area & Matters of interest for integration \\
\hline $\begin{array}{l}\text { Maintenance Planning and } \\
\text { Scheduling }\end{array}$ & $\begin{array}{l}\text { Production and maintenance function should share common objectives and } \\
\text { coordinate accordingly plans and schedules of machines' usage, considering } \\
\text { all machines and a prioritization approach to plan and schedule maintenance } \\
\text { activities. Furthermore, it is opportune to consider the availability of produc- } \\
\text { tion operators, with the purpose to develop autonomous maintenance plans. }\end{array}$ \\
\hline $\begin{array}{l}\text { Coordination for Mainte- } \\
\text { nance Execution and } \\
\text { Reporting }\end{array}$ & $\begin{array}{l}\text { Production operators need the necessary knowledge to manage a failure in a } \\
\text { standardized way, to solve problems by means of an autonomous mainte- } \\
\text { nance execution, or to identify the right person to restore the machines to the } \\
\text { normal condition. Reporting is also required for the necessary recordings of } \\
\text { activities, to suit further needs of failure analysis; reporting starts with the } \\
\text { request issued by production operators. }\end{array}$ \\
\hline $\begin{array}{l}\text { Failure Analysis and } \\
\text { Opportunistic Mainte- } \\
\text { nance }\end{array}$ & $\begin{array}{l}\text { When a failure happens, it is possible to allocate unscheduled preventive } \\
\text { maintenance as repair "opportunity"; this requires a short-term coordination } \\
\text { between production and maintenance function. }\end{array}$ \\
\hline $\begin{array}{c}\text { Failure Analysis and } \\
\text { Continuous Improvement }\end{array}$ & $\begin{array}{l}\text { Failure analysis could bring to new procedures that, inside maintenance and } \\
\text { production function, promote continuous improvement. }\end{array}$ \\
\hline $\begin{array}{l}\text { Human Resources Man- } \\
\text { agement }\end{array}$ & $\begin{array}{l}\text { Human resources are a lever for effective integration: production operators } \\
\text { should be trained on basic functions of the machines they work in, and their } \\
\text { failure modes to autonomously make some activities, and to further collabo- } \\
\text { rate with maintenance by sharing ideas for continuous improvement. }\end{array}$ \\
\hline Performance Measurement & $\begin{array}{l}\text { Performance measurement is needed to check the effectiveness of improve- } \\
\text { ments: KPIs are an important "tool", shared between production and mainte- } \\
\text { nance function, to control the adequacy of improvements. }\end{array}$ \\
\hline
\end{tabular}

\section{Implementation of the exploratory research}

\subsection{The questionnaire}

The process areas were used to guide the generation of a questionnaire for the case study analysis: the questionnaire was structured with sets of questions, one for each area, while the pilots were helpful for transforming knowledge available from literature in questions understandable in practice. The questionnaire was then used to lead a discussion with target employees in each case study, allowing to gather open answers. Table 2 provides a sample of questions for the 'Failure Analysis and Continuous Improvement' process area. Accordingly to the related tasks expected within an organization, the questions are classified by indicating the responsibilities, either only within the maintenance function $(\mathrm{M})$ or within the interaction with production function $(\mathrm{M}$ $\mathrm{P})$. The questions are also classified considering the capabilities of the maintenance function that the practices contribute to: the definition of capabilities - managerial, organizational and technological (MAN, ORG and TEC) - is based on previous works of the authors, as better explained in the next section 3.2. 
Tab. 2. Sample of questions taken out from the questionnaire and their classification

\begin{tabular}{|l|c|c|c|c|c|}
\hline \multicolumn{2}{|c|}{ Question } & \multicolumn{2}{c|}{ FUNCTON } & \multicolumn{2}{c|}{ CAPABILITY } \\
\cline { 2 - 5 } & M & M-P & ORG & TEC & MAN \\
\hline $\begin{array}{l}\text { If failure analysis is done in your tasks, do you analyze } \\
\text { the trends and statistical properties of past failures? }\end{array}$ & $\sqrt{ }$ & & & \multirow{2}{*}{} & \\
\hline $\begin{array}{l}\text { When you decide some improvement, who is consulted to } \\
\text { finally assess the decision? }\end{array}$ & & $\sqrt{ }$ & & & $\sqrt{ }$ \\
\hline $\begin{array}{l}\text { Who is in charge to check performances to monitor the } \\
\text { improvements after implementing new procedures? }\end{array}$ & & $\sqrt{ }$ & $\sqrt{ }$ & & \\
\hline
\end{tabular}

\subsection{Maturity assessment method}

The quality of a business process can be evaluated through the concept of maturity. Indeed, maturity has been proposed to assess how business processes are carried on; correspondingly, maturity assessment methods have been developed with the purpose to assess the state of practices of such processes [8]. Maturity models lead to the provision of a normative description of the good / best practices [9], which helps to develop a rank of practices in the target processes. In particular, making a rank of practices is possible through the identification of a given maturity or capability level [10]: a company, subject to a quality audit, is assigned a maturity / capability level based on the observation of its practices in the target processes. Using terms originally developed for maturity assessment methods, a Maturity Level (ML) can be assigned to a process, or to a set of processes, so called Process Area (PA); several models have been used for the definition of maturity, many of which are based on the Capability Maturity Model (CMM) and its later integrations [10]. As such, adopting the MLs can be considered a way to assess tangibly - by using a score - the state of practices in a business process / process area.

Some authors of this paper have already experienced the use of maturity assessment: a concept of maturity assessment for maintenance management was presented in [11] and tested in case studies from different industries [12, 13, 14]. More recently, the method is presented in its theory [8], inherited in the present paper in the main assumptions. Summarizing them, PAs are assessed in terms of their managerial, organizational and technological capabilities: when making a quality audit of business processes, one can analyze, at the most aggregated level, the MLs reached by a company in terms of such capabilities; afterwards, the MLs can be split to detect the criticalities through the maturity profiles, firstly, of the PAs and, after further decomposition, of their component processes. The difference of this paper, with respect to the original concept of [8], is due to the extended scope of analysis: the method is herein adopted with the purpose to study the interaction between maintenance and production management instead of only focusing on maintenance. Another difference is related to the intended use of the method: it is to support a rough analysis aimed at the identification of two MLs, high and low. This rank does not achieve a precise granularity, as it would be possible when more established approaches are adopted - e.g., those recommended by CMMI, with 5 to 6 levels. The limited use proposed for the present paper was sufficient for the purpose of the exploratory research: the maturity 
assessment helps making a rough rank of practices in the target processes; more precise granularity is required if the aim is to assist companies improving their practices.

The following procedure was then adopted for each case study: i) the case is initially analyzed through a narrative description of the interviews carried on (step 1: "written report of the interview"); the narrative description is the starting point to synthesize the state of practices in the target PAs and the emergent capabilities (step 2: "summary of the observed practices in the target PAs and subsequent capabilities"; the PAs are defined accordingly with previous Table 1); comparing all the cases, and considering the behavior resulting from the practices currently observed, the PAs are classified according to two MLs, i.e. high and low maturity; this enables to make evident their contribution to capabilities and, more in general, the quality of interaction between production and maintenance (step 3: "maturity assessment of target PAs and subsequent capabilities"). Table 3 provides the definition of managerial, organizational and technological capabilities as used in this research; Table 4 reports a sample of result for a case study, showing the outcome of step 2 and 3.

Tab. 3. Definition of managerial, organisational and technological capabilities

\begin{tabular}{|c|l|}
\hline Capability & \multicolumn{1}{c|}{ Definition } \\
\hline Managerial & $\begin{array}{l}\text { Decision making capabilities within the planning and control cycle, considering also } \\
\text { the responsibilities, either only within the maintenance function or involving the inter- } \\
\text { action with the production function. }\end{array}$ \\
\hline Organizational & $\begin{array}{l}\text { Definition of organisational roles and duties, organisational relationships between } \\
\text { production and maintenance function, and mechanisms to support knowledge manage- } \\
\text { ment, motivation and growth of human resources. }\end{array}$ \\
\hline Technological & $\begin{array}{l}\text { Support provided by ICT tools and techniques/methods for data analysis, with particu- } \\
\text { lar concern on their effective use in the company's practices (i.e. it is interesting how } \\
\text { tools/techniques/methods are effectively adopted, not solely their availability). }\end{array}$ \\
\hline
\end{tabular}

Tab. 4. Sample of a case study result

\begin{tabular}{|c|l|c|}
\hline Process area & Sample of evidences emergent for the company's capabilities & ML \\
\hline $\begin{array}{c}\text { Maintenance Planning and } \\
\text { Scheduling }\end{array}$ & $\begin{array}{l}\text { (MAN): the maintenance plan is updated every year but there are } \\
\text { weaknesses in the planning process: the decisions do not result } \\
\text { from any collaboration with production function, while the plan } \\
\text { changes are based only on special, big events worthy of remark. }\end{array}$ & L \\
\hline $\begin{array}{c}\text { Coordination for Maintenance } \\
\text { Execution and Reporting }\end{array}$ & $\begin{array}{l}\text { (ORG): the company adopts a standardized reporting process, with } \\
\text { the purpose to gather all inputs from the work request issue to the } \\
\text { work order execution; organizational roles are identified with their } \\
\text { task responsibilities along the process. }\end{array}$ & H \\
\hline $\begin{array}{c}\text { Failure Analysis and Contin- } \\
\text { uous Improvement }\end{array}$ & $\begin{array}{l}\text { (TEC): time series of past failures are not stored in electronic } \\
\text { means; their trends and statistical properties cannot be analyzed. }\end{array}$ & L \\
\hline
\end{tabular}




\section{$4 \quad$ Results of the exploratory research}

The outcome of case study analysis is now presented focusing on main features to characterize each capability (Table 5): the features are synthesizing the most meaningful observation of practices emerged through the maturity assessment in different PAs; to comply with privacy issues, the SMEs are named by an anonymous number.

Tab. 5. Cross-analysis of main features emerging in the case studies

\begin{tabular}{|l|c|c|c|c|c|c|c|c|c|c|}
\hline Features / ORG & $\mathbf{1}$ & $\mathbf{2}$ & $\mathbf{3}$ & $\mathbf{4}$ & $\mathbf{5}$ & $\mathbf{6}$ & $\mathbf{7}$ & $\mathbf{8}$ & $\mathbf{9}$ & $\mathbf{1 0}$ \\
\hline Cross-functional communication & H & H & H & H & H & H & H & H & H & H \\
\hline $\begin{array}{l}\text { Task standardization along the } \\
\text { reporting process }\end{array}$ & H & H & H & L & H & H & H & H & H & H \\
\hline $\begin{array}{l}\text { Production operator involvement in } \\
\text { maintenance }\end{array}$ & L & L & L & H & L & L & L & L & H & L \\
\hline Features / TEC & $\mathbf{1}$ & $\mathbf{2}$ & $\mathbf{3}$ & $\mathbf{4}$ & $\mathbf{5}$ & $\mathbf{6}$ & $\mathbf{7}$ & $\mathbf{8}$ & $\mathbf{9}$ & $\mathbf{1 0}$ \\
\hline IT support to condition monitoring & L & H & L & L & H & L & H & H & L & H \\
\hline $\begin{array}{l}\text { IT support to opportunistic mainte- } \\
\text { nance }\end{array}$ & L & L & L & L & L & L & H & H & L & L \\
\hline IT support to failure analysis & L & L & L & L & L & L & H & L & L & H \\
\hline Features / MAN & $\mathbf{1}$ & $\mathbf{2}$ & $\mathbf{3}$ & $\mathbf{4}$ & $\mathbf{5}$ & $\mathbf{6}$ & $\mathbf{7}$ & $\mathbf{8}$ & $\mathbf{9}$ & $\mathbf{1 0}$ \\
\hline $\begin{array}{l}\text { Alignment of maintenance planning } \\
\text { with requirements }\end{array}$ & L & L & L & L & L & L & H & H & L & H \\
\hline $\begin{array}{l}\text { Decoupling of production and } \\
\text { maintenance programs }\end{array}$ & H & H & H & H & H & H & H & H & H & H \\
\hline $\begin{array}{l}\text { Decision criteria for opportunistic } \\
\text { maintenance }\end{array}$ & L & L & L & L & L & L & H & H & L & L \\
\hline $\begin{array}{l}\text { Standard KPIs driving performance } \\
\text { management }\end{array}$ & L & L & L & L & L & L & H & H & H & H \\
\hline
\end{tabular}

A good maturity is evident for the organizational capability, especially in: i) the cross-functional communication, facilitated by the simple organizational structure; ii) the standardization of the reporting process, with task responsibilities of different functions along the process; this enables gathering all inputs required for work order management, from work request issue to order execution. Conversely, serious weaknesses regard the involvement of production operators in the execution of autonomous maintenance: in almost all the companies, production operators are forbidden to execute any maintenance activity on machines; further on, training only aims at guaranteeing skills to correctly use the machines and to identify particular symptoms that the failure has occurred or is close to occur; all in all, there is a clear separation between production and maintenance functions at the execution level.

A poor maturity is evident in most of the sampled companies for what concern the technological capability, due to a low maturity in: i) the scheduling of opportunistic maintenance, not relying on a tool that, based on the information of machines' expected workload and maintenance downtimes, could support the planner in more in- 
formed decisions; ii) the storage of failure reports, kept in paper forms in case of nonmature companies; this causes hard consultation and analysis of past events. On the other hand, the IT support to condition monitoring of machines is exploited in half of the sampled companies: this is a promising issue for mature practices.

Managerial capability did not result mature, except for maintenance scheduling. Maintenance scheduling is eased in all companies by cyclic programs in case of regular stoppages for frequent activities (every Saturday) or longer durations (once or twice a year): the maintenance function can manage the programs autonomously, and there is no real need for coordination with the production function, thanks to a decoupling mechanism defined through simple rules (e.g. Saturday is only dedicated to maintenance, and it is scheduled once every week, or every more weeks). On the other hand, many weaknesses arise, such as the followings: i) maintenance planning is carried on once a year, even if decisions concerning preventive maintenance frequencies are not aligned with the actual requirements, being not driven neither by an analysis of failure trends nor by the production needs arising from the demand forecast; ii) scheduling of opportunistic maintenance is not engineered in its decision criteria, because the analysis of maintenance downtimes is usually missing and, further on, scheduling is not based on a priority list of activities, which could guide opportunistic decisions; iii) performance management is not currently observed; in particular, management driven by performances such as OEE is missing; as positive remarks, it is however opportune to point out that some KPIs - i.e. production yield and productivity -, which can be related to the OEE components - i.e. quality, availability and performance -, are used in the most mature cases.

\section{Conclusions}

The exploratory research of this paper has provided first evidences on practices used in manufacturing SMEs to improve maintenance thanks to its integration with production: a wide number of weaknesses, concerning managerial and technological capabilities, are revealed, while organizational capabilities seem more robust. Future works will continue the research focusing in other districts and industries. The purpose will be to enlarge the sample and make a cross-analysis of different SMEs context. It will be relevant to identify the common weaknesses, then the correspondent gaps, to establish a further research phase aimed at technology transfer helpful to SMEs.

\section{$6 \quad$ References}

1. Cholasuke, C., Bhardwa, R., Antony, J.: The status of maintenance management in UK manufacturing organisations: results from a pilot survey. Journal of Quality in Maintenance Engineering 10 (1), 5-15 (2004).

2. Swanson, L.: Linking maintenance strategies to performance. International Journal of Production Economics, 70, 237-244 (2001). 
3. Pinjala, S.K., Pintelon, L., Verecka, A.: An empirical investigation on the relationship between business and maintenance strategies. International Journal of Production Economics, 104, 214-229 (2006).

4. Alsyouf I.: Maintenance practices in Swedish industries: Survey results. International Journal of Production Economics, 121, 212-223 (2009)

5. TeSeM: Offrire valore gestendo la manutenzione come un'impresa: utopia o sfida reale?, yearly report, available at: http://www.tesem.net/english-site (accessed 15th May 2012). Report TeSeM (2012).

6. Cooke, F.L.: Implementing TPM in plant maintenance: some organisational barriers. International Journal of Quality \& Reliability Management, 17 (9), 1003-1016 (2000)

7. Ahuja, I.P.S., Khamba, J.S.: Total productive maintenance: literature review and directions. International Journal of Quality \& Reliability Management, 25 (7), 709-756 (2008).

8. Macchi, M., Fumagalli, L.: A maintenance maturity assessment method for the manufacturing industry. Journal of Quality in Maintenance Engineering, 19 (3), 295-315, (2013).

9. Volker, L., Van der Lei, T.E., Ligtvoet, A.: Developing a maturity model for infrastructural asset management systems. In: Proceedings of 10th Conference on Applied Infrastructure Research - Infraday 2011, 7-8 October, Berlin. TU Berlin, Beckers, T. and Von Hirschhausen, C (Eds.) (2011)

10. CMMI Product Team: CMMI -SVC, Version 1.3, Carnegie Mellon Univ., Pittsburgh, PA, USA (2010).

11. Garetti, M., Macchi, M., Terzi, S., Fumagalli, L.: Investigating the organizational business models of maintenance when adopting self diagnosing and self healing ICT systems in multi site contexts. In: Proceedings of the IFAC CEA (Conference on Cost Effective Automation in Networked Product Development and Manufacturing), Monterrey, Mexico (2007).

12. Fumagalli, L., Elefante, D., Macchi, M., Iung, B.: Evaluating the role of maintenance maturity in the adoption of new ICT in the process industry, Proceedings of 9th IFAC Workshop on IMS (Intelligent Manufacturing Systems), Szczecin, Poland (2008).

13. Gomez Fernandez, J.F., Fumagalli, L., Macchi, M., Crespo Marquez, A:. A scorecard approach to investigate the IT in the Maintenance Business Models, Proceedings of the Annual 10th International Conference on The Modern Information Technology in the Innovation Processes of the Industrial Enterprises, Prague, Czech Republic (2008).

14. Macchi, M., Fumagalli, L., Pizzolante, S., Crespo Marquez, A., Gomez Fernandez, J.F.: Towards e-Maintenance: maturity assessment of maintenance services for new ICT introduction, Proceedings of the APMS 2010 conference, Como, Italy (2010). 